\title{
Could there be a superhuman species?
}

\author{
Article
}

Accepted Version

Oderberg, D. S. (2014) Could there be a superhuman species? The Southern Journal of Philosophy, 52 (2). pp. 206-226. ISSN 0038-4283 doi: https://doi.org/10.1111/sjp.12057 Available at https://centaur.reading.ac.uk/39607/

It is advisable to refer to the publisher's version if you intend to cite from the work. See Guidance on citing.

To link to this article DOI: http://dx.doi.org/10.1111/sjp.12057

Publisher: Department of Philosophy, University of Memphis

All outputs in CentAUR are protected by Intellectual Property Rights law, including copyright law. Copyright and IPR is retained by the creators or other copyright holders. Terms and conditions for use of this material are defined in the End User Agreement.

\section{www.reading.ac.uk/centaur}

\section{CentAUR}

Central Archive at the University of Reading

Reading's research outputs online 
WARNING - AUTHOR COPY ONLY. NOT OFFICIAL PUBLICATION. NOT

FOR CITATION. OFFICIAL VERSION IS PUBLISHED IN: The Southern Journal of Philosophy 52 (2014): 206-26

\title{
Could There Be A Superhuman Species?
}

\author{
David S. Oderberg
}

\section{Abstract: WARNING - AUTHOR'S DRAFT ONLY! \\ Transhumanism jo the school of thought that advocates the use of \\ technology to enhance the human species, to the point where some \\ SEE ABOVE FOR OFFICIAL PUBLISHED}

supporters consider that a new species altogether could arise. Even some VERSION.

critics think this at least a technological possibility. Some supporters also believe the emergence of a new, improved, superhuman species raises no special ethical questions. Through an examination of the metaphysics of species, and an analysis of the essence of the human species, I argue that the existence of an embodied, genuinely superhuman species is a metaphysical impossibility. Finally, I point out an interesting ethical consideration that this metaphysical truth raises.

Keywords: transhumanism, posthumanism, species, essentialism

\section{Introduction}

Transhumanism is a hydra-headed movement embracing a multitude of streams of thought. At the more moderate end, transhumanists advocate 
WARNING - AUTHOR COPY ONLY. NOT OFFICIAL PUBLICATION. NOT

FOR CITATION. OFFICIAL VERSION IS PUBLISHED IN: The Southern Journal of Philosophy 52 (2014): 206-26

the use of technology ${ }^{1}$ and 'applied reason' with the aim of

'fundamentally improving the human condition'. ${ }^{2}$ At the more radical end, transhumanists promote the use of technology for such things as:

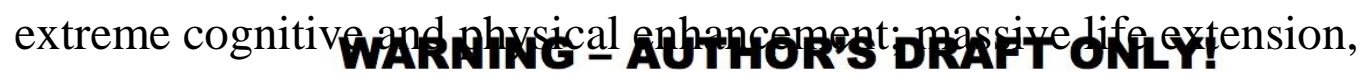
even physical or metal immortality the abolition of all human suffering; the elimination of gender; hastening the 'technological singularity", in SEE ABOVE FOR OFFICIAL PUBLISHED

which, through artificial intelligence, biological enhancement and/or VERSION.

biological-mechanical synthesis, superintelligence emerges, outstripping mere human intelligence; and sundry other objectives.

${ }^{1}$ In particular the so-called NBIC technologies: nanotechnology, biotechnology, information technology, and cognitive science. The acronym came into public use via the National Science Foundation-funded report edited by M.C. Roco and W.S.

Bainbridge, Converging Technologies for Improving Human Performance

(Dordrecht: Kluwer, 2003), available online at http://www.wtec.org/ConvergingTechnologies/Report/NBIC_report.pdf [accessed 4 Jan. 2012].

${ }^{2}$ N. Bostrom, 'The Transhumanist FAQ', pub. World Transhumanist Association, v.2.1 (2003): 4, at http://www.transhumanism.org/resources/FAQv21.pdf [accessed 4 Jan. 2012].

${ }^{3}$ A term introduced by the science fiction writer Vernor Vinge in the 1980 s and 1990s, and popularized by the futurist Ray Kurzweil in 2005. For further references and historical background, see D.J. Chalmers, 'The Singularity: A Philosophical Analysis', esp. sec. 1, Journal of Consciousness Studies 17 (2010): 7-65. 
WARNING - AUTHOR COPY ONLY. NOT OFFICIAL PUBLICATION. NOT

FOR CITATION. OFFICIAL VERSION IS PUBLISHED IN: The Southern Journal of Philosophy 52 (2014): 206-26

I want to focus on one of the more extreme claims of a minority of

transhumanists - that enhancement technologies could, through

'participant evolution', be used to create an entirely new species. This

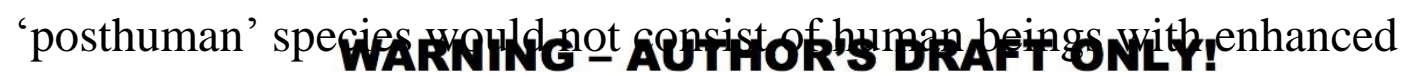

abilities - mere transhuman ${ }^{4}$ - but of a new kind of being, wholly

superior to humans in sufficient respects for it plausibly to be called a

SEE ABOVE FOR OFFICIAL PUBLISHED

distinct species. Who makes such a claim or at least thinks it a

VERSION.

possibility? The scenario is entertained as a technological possibility by

Lee Silver. ${ }^{5}$ David Chalmers implicitly thinks so as well, when he says in passing: 'given the choice between emulating and enhancing human beings and creating an objectively better species, it is possible to see the moral calculus as going either way. ${ }^{6}$ John Harris also thinks induced speciation is possible but does not consider it to have any distinctive ethical dimension. ${ }^{7}$ The roboticist Hans Moravec expects intelligent

\footnotetext{
${ }^{4}$ The terminology in this area is fluid, with the same term sometimes given different meanings and conversely. My use of 'transhuman' and 'posthuman', although somewhat stipulative, seems to be in line with common usage among transhumanists.

${ }^{5}$ L.M. Silver, Remaking Eden (New York: Avon Books, 1997).

6 'The Singularity': 33.

${ }^{7}$ John Harris, Enhancing Evolution: The Ethical Case for Making Better People (Princeton: Princeton University Press, 2007): 37-9.
} 
WARNING - AUTHOR COPY ONLY. NOT OFFICIAL PUBLICATION. NOT

FOR CITATION. OFFICIAL VERSION IS PUBLISHED IN: The Southern Journal of Philosophy 52 (2014): 206-26

machines to take over the earth as a new species dominating mankind ${ }^{8}$

(often referred to as 'apocalyptic AI' or the 'apocalyptic scenario"').

Some critics of transhumanism also assume that technology could in

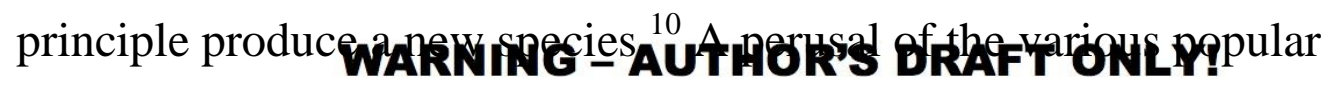
outlets for transhumanist thought shows that posthuman speciation,

whether directed or a result of ongoing natural processes, is considered at SEE ABOVE FOR OFFICIAL PUBLISHED

least a possibility if not highly likely. ${ }^{11}$

VERSION.

\section{Some brief stage setting on the metaphysics of species}

When it comes to the question of what a species is, what we have is not an embarrassment of riches but a simple embarrassment. On one oft-cited count, there are over twenty 'species concepts' in current debate, each

${ }^{8}$ H. Moravec, Robot: Mere Machine to Transcendent Mind (New York: Oxford University Press, 1999).

${ }^{9}$ R.M. Geraci, Apocalyptic AI (New York: Oxford University Press, 2010).

${ }^{10}$ G. J. Annas, L. B. Andrews, and R. M. Isasi, 'Protecting the Endangered Human:

Toward an International Treaty Prohibiting Cloning and Inheritable Alterations', American Journal of Law and Medicine 28 (2002):151-178, at pp.153-4, 161-2, 173.

${ }^{11}$ See, for example, the interview with geneticist Bruce Lahn in $h+$ magazine, one of the most prominent transhumanist publications:

http://hplusmagazine.com/2011/05/12/bruce-lahn-interview/ [accessed 5 Jan. 2012]. 
WARNING - AUTHOR COPY ONLY. NOT OFFICIAL PUBLICATION. NOT

FOR CITATION. OFFICIAL VERSION IS PUBLISHED IN: The Southern Journal of Philosophy 52 (2014): 206-26

with its philosophical and/or biological advocates. ${ }^{12}$ Part of the reason for this bewildering array of proposals is the tendency of many biologists to ignore the crucial philosophical element of the 'species problem', treating

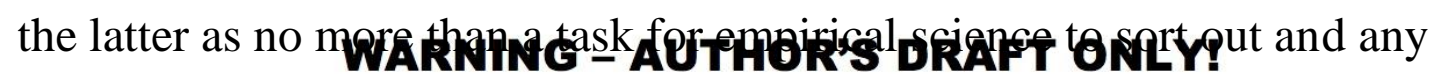
philosophizing about it to be obscurely metaphysical Combine this with a natural tendency to pragmatism and instrumentalism (in the loose SEE ABOVE FOR OFFICIAL PUBLISHED

sense) among working scientists, and we have some explanation for the VERSION.

willingness of not a few theorists about species to let a hundred flowers bloom: what a species is depends on your theoretical interests, how you carve up the world of individual organisms, and so on. ${ }^{13}$

${ }^{12}$ R.L. Mayden, 'A Hierarchy of Species Concepts: The Denouement in the Saga of the Species Problem', in M. F. Claridge, H. A. Dawah, and M. R. Wilson, (eds) Species: The Units of Biodiversity (London: Chapman and Hall, 1997): 381-424. For an overview of twenty-six species concepts (Mayden has at least twenty-two), see J. Wilkins, 'Species, Kinds, and Evolution', Reports of the National Center for Science Education 26 (2006): 36-45; available at http://ncse.com/rncse/26/4/specieskinds-evolution [accessed 5 Jan. 2012].

${ }^{13}$ Philip Kitcher is a prominent defender of pluralism: 'Species', in M. Ereshefsky (ed.) The Units of Evolution: Essays on the Nature of Species (Cambridge, MA:

Bradford Books, 1992): 317-41. See further R.A. Richards, The Species Problem: A Philosophical Analysis (Cambridge: Cambridge University Press, 2010): ch.5. 
WARNING - AUTHOR COPY ONLY. NOT OFFICIAL PUBLICATION. NOT

FOR CITATION. OFFICIAL VERSION IS PUBLISHED IN: The Southern Journal of Philosophy 52 (2014): 206-26

It is the lack of seriousness in some quarters about the

philosophical component of the species problem that is my concern here.

To be sure, many others - such as Michael Ghiselin ${ }^{14}-$ take the

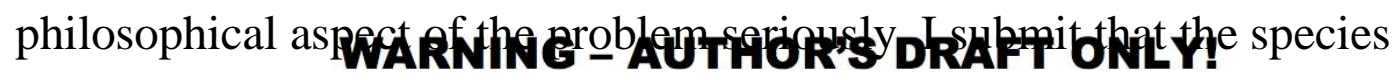

problem just is aphilosophicalproblem -insoluble without careful

attention to the biological facts, but not tractable at the level of biology

SEE ABOVE FOR OFFICIAL PUBLISHED

itself. Specifically, when asking what a species is, we are asking a

VERSION.

metaphysical question about the real definition of an organism. ${ }^{15}$ The

definition provides the constituents of the essence of the species and of

the organisms that belong to it. At this point many if not most biologists

and philosophers of biology will switch off: if what I am arguing for

depends on biological essentialism, then the argument must go wrong

somewhere. ${ }^{16}$ So here is an attempt at eirenicism: my answer to the

14 'The species problem has to do with biology, but it is fundamentally a philosophical

problem': see M. Ghiselin, 'A Radical Solution to the Species Problem',

Systematic Zoology 23 (1974): 536-544; reprinted in Ereshefsky (ed.), The Units of

Evolution: 279-92; quotation from p.285.

15 This applies in general to any object, but I restrict the term 'species' here to its

biological use.

${ }^{16}$ Biological essentialism is, though, undergoing a small revival. See David S.

Oderberg, Real Essentialism (London: Routledge, 2007), and also: D. Walsh,

'Evolutionary Essentialism', British Journal for the Philosophy of Science 57 (2006): 
WARNING - AUTHOR COPY ONLY. NOT OFFICIAL PUBLICATION. NOT

FOR CITATION. OFFICIAL VERSION IS PUBLISHED IN: The Southern Journal of Philosophy 52 (2014): 206-26

question of whether there could be a distinct 'superhuman' species

requires only a few modest assumptions which, whilst they might with

further argument entail full-blown essentialism, do not require the latter

for the argument forfthifeh: AUTHOR'S DRAFT ONLY!

Assumption ${ }_{\text {NOT }}$ There are definite answers to at least some

questions of the form 'Is $a$ the same species as $b$ ?'

SEE ABOVE FOR OFFICIAL PUBLISHED

Assumption 2: There are criteria for providing those definite VERSION.

answers.

Assumption 3: Whilst we might not have metaphysically

necessary and sufficient conditions for species identity, there

are at least some cases in which we have metaphysically

sufficient conditions.

As to the first assumption, all we need to admit is that some kinds of organism clearly belong to the same species no matter how you plausibly slice the biological cake, and others to different species. Tom and Jerry belong to different species; Clever Hans and Sea Biscuit belong to the same species, without a shadow of a doubt. As to the third assumption: in any possible world - restrict accessibility if you wish to nomologically identical worlds - in which an organism is a water-

425-48; M. Devitt, 'Resurrecting Biological Essentialism', Philosophy of Science 75 (2008): 344-82. 
WARNING - AUTHOR COPY ONLY. NOT OFFICIAL PUBLICATION. NOT

FOR CITATION. OFFICIAL VERSION IS PUBLISHED IN: The Southern Journal of Philosophy 52 (2014): 206-26

dwelling vertebrate with gills in the mature case, that organism is a fish.

In any world, any organism that breathes air, produces and regulates its temperature from within its own bodily surface, has hair, three middle ear

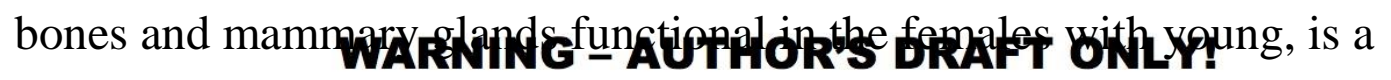
mammal. It's not simply that we have stipulated that all sych organisms be called 'mammals', but that they all have sufficient in common to be SEE ABOVE FOR OFFICIAL PUBLISHED

definitely of the same species. Note well: I am not restricting the term

\section{VERSION.}

'species' to metaphysically infima species, as per biological taxonomy, but to any natural kind of organism in the hierarchy of classification (in other words, any taxon). This is one way in which there is a fundamental metaphysical component to questions of kind membership: we are interested in all the real, objective groupings of organisms, not just those at the lowest level. (In biological taxonomy, mammals are at the level of class.)

What about the second assumption, that there are criteria - nonarbitrary, non-conventional, and so on - for determining answers to some questions of species identity? The species problem bites back hard at this point, but all I can do here is state that the criteria I favour are morphological: they appeal to the appearance, structure, and characteristic function of organisms - morphē in all its traditional Aristotelian glory. The general reason in favour of morphology over other 
WARNING - AUTHOR COPY ONLY. NOT OFFICIAL PUBLICATION. NOT

FOR CITATION. OFFICIAL VERSION IS PUBLISHED IN: The Southern Journal

of Philosophy 52 (2014): 206-26

criteria is that all the others seem, in one way or another, either to

piggyback on morphology or to sidestep it in favour of other

considerations that to the unprejudiced eye look simply irrelevant. For

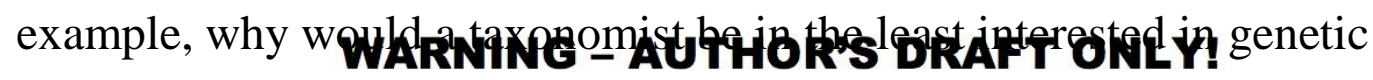

criteria if they did not correlate closely with appearance structure, and

function? In fact they do, as we know; and so the only reason to be

SEE ABOVE FOR OFFICIAL PUBLISHED

interested in them as markers of species identity is that different genes

VERSION.

express different characteristics, whether at the macro- or micro-level.

For suppose you had two organisms with identical genotypes and yet

different morphologies. (Maybe Tom and Jerry, in some world, turn out

to be genetically identical.) What possible reason would there be for

insisting on their belonging to the same species in that world? ${ }^{17}$ Suppose

${ }^{17}$ A nice example, illustrating what is called 'cryptic speciation', is the recent discovery that the freshwater worm called Lumbriculus variegatus is actually two distinct species differing in DNA, despite the identity in appearance of all specimens and their similar natural locations. One of the researchers, Christer Erséus, said:

'Different species have different characteristics. If it emerged that these two species differ in terms of their tolerance towards certain toxins, then it could be difficult to make comparisons between different studies.' The point, for our purposes, is that the mere genetic difference does not - and should not - matter. What is important is whether this shows up in differences of characteristic behaviour and function, such as toxin resistance. And that is a matter of morphology. (Mere visual appearance is never 
WARNING - AUTHOR COPY ONLY. NOT OFFICIAL PUBLICATION. NOT

FOR CITATION. OFFICIAL VERSION IS PUBLISHED IN: The Southern Journal of Philosophy 52 (2014): 206-26

Sea Biscuit and Clever Hans had virtually none of their genes in

common. (They would have to have some, being animals; suppose they

both had the same Hox genes ${ }^{18}$ and the same Boule gene, ${ }^{19}$ but nothing

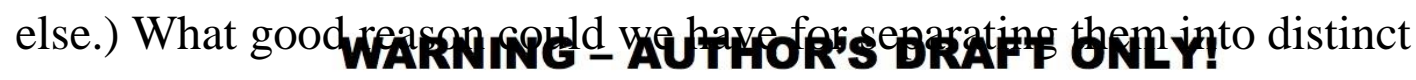
species, assuming their morphologies were exactly the same as in our

world where their genotypes massively overlap? It is beside the point to SEE ABOVE FOR OFFICIAL PUBLISHED

reply that morphology is (in some appropriate sense) determined by VERSION.

genetics: we can adhere to morphological criteria of identity without

denying that morphology has an underlying cause. We are interested in the criteria, not their causes - except insofar as the causes have certain effects - and if the causes in the actual world were different in some other world, while morphology was held constant, this would not imply that morphology ceased to be the proper identity criterion. In brief, if you are

the whole morphological story.) See further D.A. Price and C. Erséus, 'Genetic variation in the popular lab worm Lumbriculus variegatus (Annelida: Clitellata:

Lumbriculidae) reveals cryptic speciation', Molecular Phylogenetics and Evolution 51 (2009): 182-9; and the article 'Animals That Seem Identical May Be Completely

Different Species', ScienceDaily, 22 April 2009, at http://www.sciencedaily.com/releases/2009/04/090422121858.htm [last accessed 16 April 2012].

${ }^{18}$ Regulating body plan development.

${ }^{19}$ Regulating gametogenesis. 
WARNING - AUTHOR COPY ONLY. NOT OFFICIAL PUBLICATION. NOT

FOR CITATION. OFFICIAL VERSION IS PUBLISHED IN: The Southern Journal of Philosophy 52 (2014): 206-26

interested in species identity, why care about genes except for what they $d o ?$

An example of irrelevance, on the other hand, comes from the

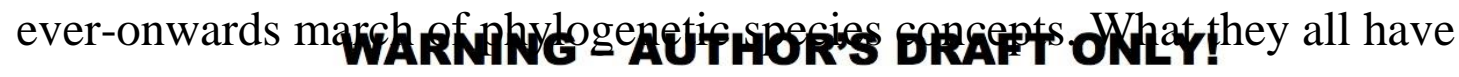
in common is the focuson exolutiongry origin as the criterion of

demarcation. Cladistics, for instance, holds that species (and higher taxa, SEE ABOVE FOR OFFICIAL PUBLISHED

but recall that I am using 'species' to include all taxa) are sections of the VERSION.

tree of life marked by branching points and most recent common ancestors. $^{20}$ The motivation behind origin-based species concepts is to bring the admittedly messy state of current taxonomy into some sort of order by aligning it with what we know about the evolutionary descent of organisms. Cladism itself has a number of problems, ${ }^{21}$ but the more general worry about all phylogenetic concepts is why anyone should want to mix classification with origin. After all, with enough knowledge we could track the evolution (in the loose sense) of all the chemical elements since the Big Bang. Hydrogen, so physicists think, came into existence at least three minutes after the origin of the universe. ${ }^{22}$ They have a model of how it and many other elements were synthesized over time out of pre-

\footnotetext{
${ }^{20}$ See, for example, M. Ridley, Evolution (Oxford: Blackwell, 1993).

${ }^{21}$ See Oderberg, Real Essentialism: ch.9.2.

${ }^{22}$ S. Weinberg, The First Three Minutes (London: Fontana, 1983): 16.
} 
WARNING - AUTHOR COPY ONLY. NOT OFFICIAL PUBLICATION. NOT

FOR CITATION. OFFICIAL VERSION IS PUBLISHED IN: The Southern Journal of Philosophy 52 (2014): 206-26

existing particles. Yet this is not how we classify hydrogen, or helium, or

for that matter gold and lead. We classify them by appearance (not

necessarily at the macro level, of course), chemical and physical

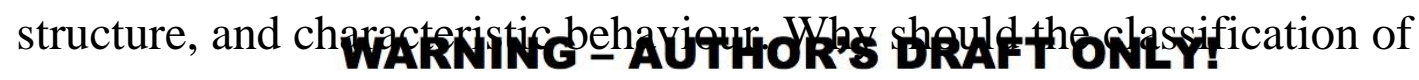
biological species be any different other than due to the misguided idea an ideological prejudice, I would call it - that if we inject phylogeny into

\section{SEE ABOVE FOR OFFICIAL PUBLISHED}

the very concept of what a species is and how species differ from one

\section{VERSION.}

another, and can arrive at a workable system of classification, we shall

have an indirect methodological vindication of evolution itself? It is hard

to see how the same approach applied to chemical classification would yield indirect vindication of the Big Bang model. More importantly, it is difficult to understand how what a thing is can have anything to do where it came from unless the thing itself is independently understood to be historical in nature - such as a familial lineage, or a history, or maybe a legend. We cannot, however, say that biological taxonomy must appeal to lineage because species are essentially historical: not only because I am not presupposing full-blown essentialism here, but because to do so would evidently be circular, assuming that the only reason for thinking species to be essentially historical is that they are defined by their ancestry. 
WARNING - AUTHOR COPY ONLY. NOT OFFICIAL PUBLICATION. NOT

FOR CITATION. OFFICIAL VERSION IS PUBLISHED IN: The Southern Journal of Philosophy 52 (2014): 206-26

3. What are we?

Plenty more could be said about morphology as the preferred criterion of species identity; I have only been able to offer enough in favour of taking

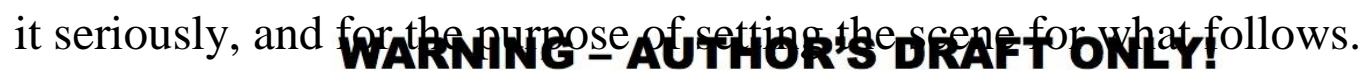
Some transhumanists, as remarked earlier think and species could be induced from our own by technology. (They take it as given that this will SEE ABOVE FOR OFFICIAL PUBLISHED

happen eventually by natural selection; they simply want to hurry things VERSION.

up.) Now whether this 'superhuman' species is indeed distinct from our own - whether it is genuinely posthuman or merely human - depends on what we are and what it is. I take what we are to be what our form is, i.e. our morphology, and that is to be a rational animal. Such is the hallowed Aristotelian definition of the human being - an animal endowed with reason.

To say that the human being is a rational animal looks, at first, very little like what you would find in a biology text. You will be told that humans are members of the species Homo sapiens, or the sub-species Homo sapiens sapiens. ${ }^{23}$ You will be informed of the descent of modern

${ }^{23}$ Depending on whether modern humans are distinguished as a sub-species of the genus homo from Homo sapiens idaltu and Homo sapiens neanderthalensis - all highly controversial to say the least, and hinging, unsurprisingly, partly on what is 
WARNING - AUTHOR COPY ONLY. NOT OFFICIAL PUBLICATION. NOT

FOR CITATION. OFFICIAL VERSION IS PUBLISHED IN: The Southern Journal of Philosophy 52 (2014): 206-26

humans via a long line of hominids; also that they are primates whose closest genetic relative is the chimpanzee or (for some biologists) the orang utan. 'Rational animal' is not a term to use in polite biological company. WARNING - AUTHOR'S DRAFT ONLY! Yet appearances can be deceptive. Sensing the truth in the very species name, when one inspects the detail, the consensus appears SEE ABOVE FOR OFFICIAL PUBLISHED unanimous that rationality is the hallmark of the human animal, whether VERSION.

this be characterized in terms of abstract thought, language use, the most sophisticated technical ability, self-consciousness, introspection, moral behaviour, advanced social interaction, and so on. ${ }^{24} \mathrm{We}$ are animals, to be sure; we are set apart from all other species by rationality; so does it not follow that we are rational animals? It quickly gets more complicated, however. For suppose evidence of rationality, say in the form of handmade tools or other artefacts, were found associated with early

meant by 'species'. See, for an overview of Neanderthals, R. Lewin, Human Evolution: An Illustrated Introduction (Oxford: Blackwell, 2005; $5^{\text {th }}$ ed.): ch.27.

${ }^{24}$ See, for instance, W. Henke, 'Human Biological Evolution', in F.M. Wuketits and F.J. Ayala (eds) Handbook of Evolution vol. 2: The Evolution of Living Systems (Including Hominids) (Weinheim: Wiley-VCH, 2005): ch.6, at p.118. 
WARNING - AUTHOR COPY ONLY. NOT OFFICIAL PUBLICATION. NOT FOR CITATION. OFFICIAL VERSION IS PUBLISHED IN: The Southern Journal of Philosophy 52 (2014): 206-26

hominids, several million years before the appearance of Homo sapiens. ${ }^{25}$

Homo habilis, considered a precursor of Homo sapiens, may have made and used tools in a human-like way. Maybe he was rational, for all we

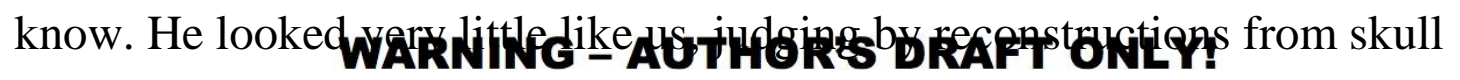
fragments. For the biologist then it is not just rationality but quite specific bodily shape and structure that make for a genuine human being. SEE ABOVE FOR OFFICIAL PUBLISHED

Moreover, were we non-specialists to see Homo habilis crossing the road, VERSION.

we would hardly acknowledge him to be 'one of us'.

Yet why wouldn't we? A relatively cheap remark invites itself here, to the effect that humans have long had false opinions about which beings were human: consider Ota Benga, the African pygmy put on display in the Bronx Zoo in 1906 with an orang utan and a parrot. ${ }^{26}$ In the present day, even, the Bantu consider pygmies 'not truly human'. ${ }^{27} \mathrm{~A}$ more substantive point in favour of making a species distinction is the phylogenetic one: Homo habilis came before Homo sapiens. But

${ }^{25}$ For speculation on this, see R.L. Susman, 'Fossil Evidence for Early Hominid Tool Use', Science 265 (1994): 1570-3.

${ }^{26}$ P.V. Bradford and H. Blume, Ota Benga: The Pygmy in the Zoo (New York: St Martin's Press, 1992).

${ }^{27}$ P. Raffaele, 'The Pygmies' Plight', Smithsonian Magazine, Sept. 2008, at http://www.smithsonianmag.com/people-places/The-Pygmies-

Plight.html?c=y\&page $=1$ [last accessed 6 Jan. 2012]. 
WARNING - AUTHOR COPY ONLY. NOT OFFICIAL PUBLICATION. NOT

FOR CITATION. OFFICIAL VERSION IS PUBLISHED IN: The Southern Journal of Philosophy 52 (2014): 206-26

wouldn't this reason on its own merely beg the question of why temporal priority in the phylogenetic tree should make a difference? More precisely, the circularity involved in appealing solely to temporal priority

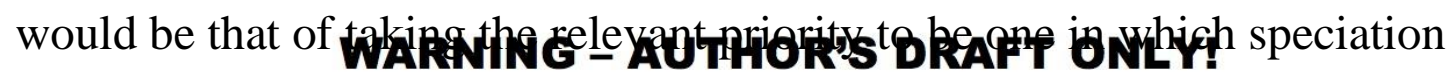
is assumed. In other words, there is an innocentreading of 'temporally prior', namely that Homo habilis existed before (or long before) Homo SEE ABOVE FOR OFFICIAL PUBLISHED

sapiens, to which the response is - so what? And there is a non-innocent VERSION.

reading, according to which Homo habilis is not human - not one of us humans - because it is an earlier species in the phylogenetic tree. Clearly this will not do.

That it does not do is shown by the fact that taxonomists do not appeal to mere temporal priority: such an appeal is more the stuff of casual banter that is the staple of popular discourse about evolution. For palaeoanthropologists tell us also that Homo habilis was, bodily, very unlike modern humans, with less than half the brain size, disproportionately long arms, and a distinctively ape-like appearance. ${ }^{28}$ But the question then arises: why should any of that make a difference? After all, if humans are rational animals, then Homo habilis, on the assumption I made about rationality, would also count as human - not

\footnotetext{
${ }^{28}$ For an overview, see B. Wood and M. Collard, 'The Human Genus', Science 284 (1999): 65-71.
} 
WARNING - AUTHOR COPY ONLY. NOT OFFICIAL PUBLICATION. NOT

FOR CITATION. OFFICIAL VERSION IS PUBLISHED IN: The Southern Journal of Philosophy 52 (2014): 206-26

merely a member of the genus Homo as taxonomists now have it, but as

one of us, metaphysically speaking. But let me put our putative ancestors to one side and take on far more radical scenarios, for if the case can be

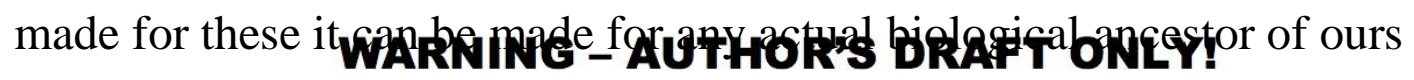
that was also rational. FOR CITATION OR CIRCULATION.

\section{SEE ABOVE FOR OFFICIAL PUBLISHED}

\section{Exotic rational animals}

\section{VERSION.}

John Locke famously thought that a rational parrot would be a person but not a human being. Rational parrots would, he considered, 'have passed for a race of rational animals' but they would nevertheless have been parrots, not men: 'For I presume it is not the idea of a thinking or rational being alone that makes the idea of a man in most people's sense: but of a body, so and so shaped, joined to it: and if that be the idea of a man, the same successive body not shifted all at once, must, as well as the same immaterial spirit, go to the making of the same man. ${ }^{29}$ Leibniz does not demur: 'there is no obstacle to there being rational animals of some other species than ours.... Indeed it does seem that the definition of "man" as "rational animal" needs to be amplified by something about the shape and

\footnotetext{
${ }^{29}$ J. Locke, An Essay Concerning Human Understanding: II.xx vii.8, P.H. Nidditch (ed.) (Oxford: Clarendon Press, 1975): 332-5.
} 
WARNING - AUTHOR COPY ONLY. NOT OFFICIAL PUBLICATION. NOT

FOR CITATION. OFFICIAL VERSION IS PUBLISHED IN: The Southern Journal of Philosophy 52 (2014): 206-26

anatomy of the body; otherwise, according to my views, Spirits would also be men." 30

Is this view, accepted by pretty much every philosopher at least

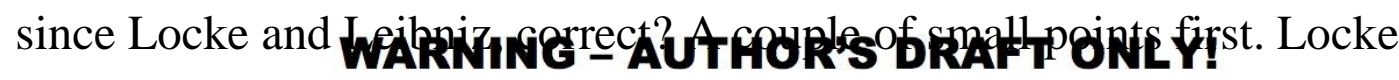
speaks of 'the idea of aman inmost people's sense' what we might call the nominal idea or perhaps nominal definition of 'man'. Reference to SEE ABOVE FOR OFFICIAL PUBLISHED

body plan will be found in any dictionary or encyclopaedia entry for

\section{VERSION.}

'human', as in academic texts. But this nominal idea might be wrong.

Maybe we just haven't thought about the issue hard enough. The first

fishermen may well have thought that all fish had scales, but they would have been wrong. The second point is that Leibniz thinks that without supplementing 'rational animal' with reference to the 'shape and anatomy of the body', spirits would also be men. Yet this does not follow, since spirits by definition are not animals and do not have bodies at all.

A mistake about whether all fish have scales looks purely the result of inadequate empirical information. Yet when it comes to classification, it is hard to separate the empirical and the metaphysical components. It is an empirical matter whether catfish have scales (they do not), but a largely metaphysical matter whether they are still to be classified as fish.

\footnotetext{
${ }^{30}$ G.W. Leibniz, New Essays on Human Understanding: II.xxvii.8, P. Remnant and J. Bennett (eds) (Cambridge: Cambridge University Press, 1996): 234-5.
} 
WARNING - AUTHOR COPY ONLY. NOT OFFICIAL PUBLICATION. NOT

FOR CITATION. OFFICIAL VERSION IS PUBLISHED IN: The Southern Journal of Philosophy 52 (2014): 206-26

That they behave in a characteristic way similar enough to a certain class of other water-dwellers to be counted as members of that class is a matter of abstracting what is common to particular empirical cases, and this is a

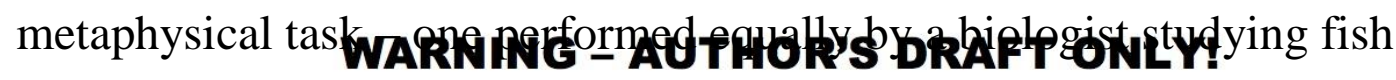
and (with less overall accuracy) by a fisherman trawling a lake.

So if we assumed Locke to be mistaken about the rational parrot, SEE ABOVE FOR OFFICIAL PUBLISHED

we could not conclude that this must be due to a mere lack of empirical VERSION.

information and then wonder (for reductio purposes) what this could possibly be. Still, this could be the cause. Locke has the parrot carrying out a few simple conversations in 'Brazilian', ${ }^{31}$ but what if we augmented its talent by giving it the full panoply of human conversational ability? What if it could pass an avian version of the Turing Test, its squawky voice suitably masked to sound like that of a middle-aged woman? To the question, 'How could you possibly think this was a human?', knowing now that our interlocutor had the body of a parrot, why could one not riposte: 'And how could anyone possibly think this was a parrot?'

Which is where the threat of stalemate looms, unless broken by the seemingly compulsory move of classifying Locke's parrot as a person of a different species to humans and parrots. Note: this is not the move

\footnotetext{
${ }^{31}$ From which anyone would conclude this was just a very well-trained parrot though Locke takes it as proof of rationality.
} 
WARNING - AUTHOR COPY ONLY. NOT OFFICIAL PUBLICATION. NOT

FOR CITATION. OFFICIAL VERSION IS PUBLISHED IN: The Southern Journal of Philosophy 52 (2014): 206-26

Locke makes. Nowhere does he assert that what seems to be a parrot is a person of an altogether different species. Rather, he makes it quite clear that the creature in question is both a person and a parrot, an intuition

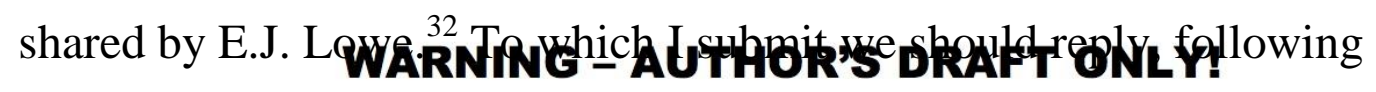
Kripke and Putnam that such a creature yould be nomore a parrot than a pencil could (in the metaphysical sense) be an organism or a cat could be SEE ABOVE FOR OFFICIAL PUBLISHED

a robot. ${ }^{33}$ Again, if there is a minimal essentialism here, so be it: whatever VERSION.

a parrot could be, it could not be a person. ${ }^{34}$ A creature with rationality

${ }^{32}$ In his review of my Real Essentialism, and in disagreement with the position expressed there on rational animals, Lowe says: 'My own intuitions in such matters accord entirely with those of Locke, as displayed in his discussion of the famous example of the "rational parrot". This parrot would be a person, surely, but not a man': Philosophical Quarterly 60 (2010): 648-52, at p.651.

${ }^{33}$ H. Putnam, 'It Ain't Necessarily So', in his Mathematics, Matter and Method:

Philosophical Papers, vol. 1 (Cambridge: Cambridge University Press, 1975): 237-49 and 'Is Semantics Possible?', in his Mind, Language and Reality: Philosophical Papers, vol. 2 (Cambridge: Cambridge University Press, 1975): 139-152; S. Kripke, Naming and Necessity (Oxford: Blackwell, 1980): 122ff. Kripke is altogether clearer about the metaphysical impossibility of cats' being robots than Putnam, but wishing to avoid exegetical issues I take Putnam's view to be the same.

${ }^{34}$ I am inserting some necessary conditions here into my minimal essentialism, to be sure, but they are all negative: I am not stating what a parrot must be, only what it 
WARNING - AUTHOR COPY ONLY. NOT OFFICIAL PUBLICATION. NOT

FOR CITATION. OFFICIAL VERSION IS PUBLISHED IN: The Southern Journal of Philosophy 52 (2014): 206-26

and the appearance of a parrot would, à la Kripke's cat-like demons, ${ }^{35}$ be

a person in a parrot-like form ('form' being used by Kripke in its

vernacular sense of 'appearance', not in the technical Aristotelian sense

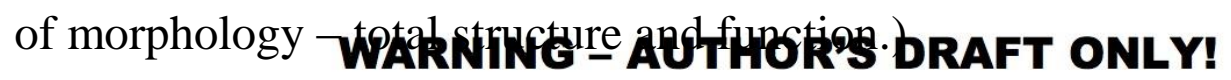

This is bytan assertion must deave unargued since the burden of

the discussion concerns, not what a so-called rational parrot could not be, SEE ABOVE FOR OFFICIAL PUBLISHED

but what it would be. And my claim is that it would be not only a person

VERSION.

but a human person, i.e. a human being. ${ }^{36}$ In other words, being a rational animal simpliciter is sufficient to make the so-called rational parrot one of us, that is, sufficiently like us to count as one of our species. The reason is that all rational animals share the two characteristics that matter most in constituting the way in which they fundamentally live and act in the world. Being rational, the rational animal has the capacity for such things as: abstract thought, that is, the ability to abstract from particulars to reach general judgments involving concepts; language; knowledge of why it does many of the things it does, what Aristotelians call knowledge

could not be; and even here I am not offering an exhaustive list of the things a parrot could not be, only one example.

${ }^{35}$ Naming and Necessity: 126.

${ }^{36}$ I make no distinctions here (or elsewhere) between human beings and human persons. 
WARNING - AUTHOR COPY ONLY. NOT OFFICIAL PUBLICATION. NOT

FOR CITATION. OFFICIAL VERSION IS PUBLISHED IN: The Southern Journal of Philosophy 52 (2014): 206-26

of finality; the conscious ordering of ends or objectives; development of and adherence to a life plan; reflection, meditation, puzzlement over, attempts to understand and resolve, matters concerning its own life, the

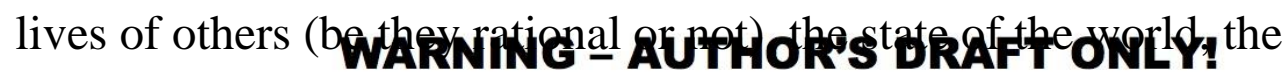
connections between things and events; a moral life with all that is entailed by a grasp of morality as a system of norms for living. We can SEE ABOVE FOR OFFICIAL PUBLISHED

easily add to the list, of course: humour, irony, aesthetic sensibility, the VERSION.

creation and maintenance of families and political societies...we all know the sorts of things we rational animals are capable of.

Now I do not wish, or need, to begin the difficult task of drawing all the logical and conceptual connections between these multifarious aspects of life as a rational animal. All I claim here is that rationality as the capacity for abstract conceptual thought is explanatorily basic relative to a large number of the sorts of characteristic listed here. Language is the most important case in point. Abstraction from particulars and ascent to the level of conceptual thought necessarily involves some kind of representational system because it essentially involves the composition and division of concepts: mental elements are put together or divided in order to make judgments, and judgments are put together to make inferences. The elements have to have some kind of meaningful structure, by which I mean a structure involving at least the basic operations of 
WARNING - AUTHOR COPY ONLY. NOT OFFICIAL PUBLICATION. NOT

FOR CITATION. OFFICIAL VERSION IS PUBLISHED IN: The Southern Journal of Philosophy 52 (2014): 206-26

reference, predication, logical operation, and the like, put together in a

certain way, such that other ways of combination are excluded. A

creature that can do all of this must have language; in fact, language is

what I have just descrikefNg - AUTHOR'S DRAFT ONLY!

One wonders moreover just what rationality could be for a

creature that did not have any of this repertoire. Ethologists with an axe

SEE ABOVE FOR OFFICIAL PUBLISHED

to grind might like to appeal to some kind of complex problem-solving,

VERSION.

or perhaps a set of specific social interactions supposedly manifesting a

highly developed sense of self and other, and the like. But to take this

tiny subset of the things that we do, the paradigmatic rational animals -

the only ones we know of in the universe - and treat it as a surrogate for

the whole says more about a prior agenda than it does about what marks

us rational animals out as distinctive among all living creatures. The

linguistic capacity is a direct result of, if not identical with, the capacity

for abstract thought, and it makes possible most of the other features

enumerated earlier. To take some feature or other and elevate it to the

status of 'mark of rationality' on its own is misleading precisely because

it draws attention to a kind of ability - problem-solving, say, or the

making of artefacts - that is language-like while severing the genuine

linguistic element that gives the ability any special interest in the first

place. 
WARNING - AUTHOR COPY ONLY. NOT OFFICIAL PUBLICATION. NOT

FOR CITATION. OFFICIAL VERSION IS PUBLISHED IN: The Southern Journal of Philosophy 52 (2014): 206-26

It is one thing, however, to insist that all rational animals have language, ${ }^{37}$ and another that they must be capable of communication. We can now bring in animality to say something about this. All rational

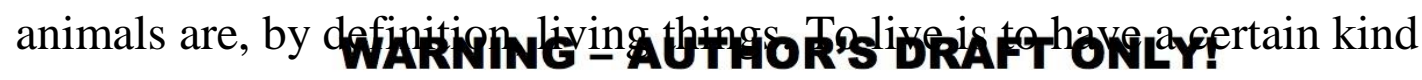
of body, one that cap sustain the so-called vegetative operations of nutrition, metabolism, reproduction, self-preservation, homeostasis, and SEE ABOVE FOR OFFICIAL PUBLISHED

so on. In addition, animals have sensation, the ability to pick up and VERSION.

process information from their environment, distinguishing the harmful from the beneficial, avoiding or repelling the former and employing the latter in the vegetative functions. Now, leaving aside the question of a

${ }^{37}$ The question as to whether rationality entails language is controversial, and my brief remarks are not intended to sweep a significant debate under the carpet. Much depends, of course, on what one means by 'rational' and by 'having language'. Fodor's 'language of thought' hypothesis, for example, relies on a computational theory of cognition and seems (given Fodor's fairly loose and occasional remarks about the matter in his The Language of Thought Revisited (Oxford: Clarendon Press, 2008)) to take paradigmatic rationality to involve certain basic inferential abilities.

The tie to language, for him, involves computation over contentful syntactic structures in Mentalese, a language not to be counted among the natural languages with which we are familiar (though it is of course natural). Although I do not regard the necessity of language to rationality as having anything essential to do with either computation or a 'language of thought', I cannot pursue the matter here. 
WARNING - AUTHOR COPY ONLY. NOT OFFICIAL PUBLICATION. NOT

FOR CITATION. OFFICIAL VERSION IS PUBLISHED IN: The Southern Journal of Philosophy 52 (2014): 206-26

singleton rational animal necessarily alone in some environment (not

something transhumanists are interested in anyway), if we have: several

rational animals, each knowing the other is rational (since rationality

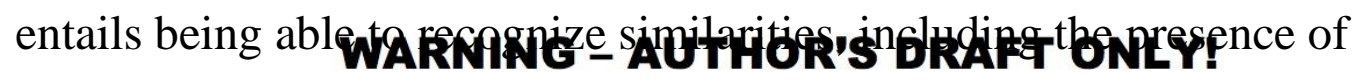
rationality outside Nopeselfat leastin some circumstances) all employing

the same generic vegetative functions, with the same generic sensory

\section{SEE ABOVE FOR OFFICIAL PUBLISHED}

abilities, in the same environment, then at the very least it is highly likely VERSION.

they will communicate with each other. Why must they be able to? Take

a simple line of thought: a rational animal will want to know the answer to something; so it will pose a question; and if it recognizes another rational animal that might know the answer, it will pose it to the other. If the animal has language, can ask a question, wants an answer, and thinks it can get one from another animal, does it not have everything it needs to be able to communicate? And if it can, why would it not? Don't we rational animals show exactly how this works?

So we can be fairly certain that all rational animals are able to communicate. What we haven't shown yet is that they can all communicate with each other. What we do know is that they can all attempt to communicate with each other, for the same reason that they can successfully communicate with some others. That some rational animals might not be interested in communicating with others is 
WARNING - AUTHOR COPY ONLY. NOT OFFICIAL PUBLICATION. NOT

FOR CITATION. OFFICIAL VERSION IS PUBLISHED IN: The Southern Journal of Philosophy 52 (2014): 206-26

irrelevant, as is the fact that rational animals suffering some kind of deformity, damage, or environmental limitation might not be able to communicate at all ('able' in the Aristotelian sense of 'first

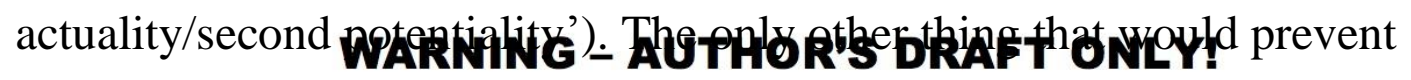
actual communication between some rational animals is a lack of uptake
NOT FOR CITATION OR CIRCULATION. due to untranslatability.

\section{SEE ABOVE FOR OFFICIAL PUBLISHED}

At this point I am quite unashamedly going to put to one side VERSION.

general questions of a Quinean sort concerning radical translation, inscrutability of reference, and underdetermination of theory by behavioural data. ${ }^{38}$ For if these are genuine problems (which I doubt), ${ }^{39}$ they are problems for all radical translation, including that between the only rational animals we know of - us in the sense of Homo sapiens. Since I am simply assuming that we Homo sapiens do successfully engage in translation as radical as we can find, ${ }^{40}$ the question is not whether, given Quinean worries, such translation is possible in general,

\footnotetext{
${ }^{38}$ W.V. Quine, Word and Object (Cambridge, MA: MIT Press, 1960) and elsewhere.

${ }^{39}$ For a useful critique, see H. Glock, Quine and Davidson on Language, Thought and Reality (Cambridge: Cambridge University Press, 2003).

${ }^{40}$ With a few exceptions such as Linear A and Etruscan, but who knows whether we will translate those one day? We managed with Egyptian hieroglyphics and Linear B despite the sceptics.
} 
WARNING - AUTHOR COPY ONLY. NOT OFFICIAL PUBLICATION. NOT

FOR CITATION. OFFICIAL VERSION IS PUBLISHED IN: The Southern Journal of Philosophy 52 (2014): 206-26

but whether there is some other reason of principle preventing it in the case of rational animals very different from us Homo sapiens - whether parrot-like rational animals, rational Martians, or some future posthuman

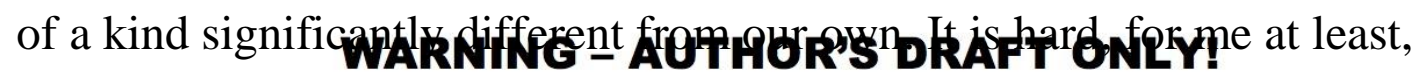
to see what sort of reason there could be apart from general sceptical

worries about whether there is a single world we and they inhabit (we and SEE ABOVE FOR OFFICIAL PUBLISHED

the rational Martian inhabit the same world even though we are on Earth VERSION.

and they are on Mars) and whether, if so, their experience of it is so radically different from our own that we simply cannot communicate with each other about what we experience.

Again, I am going simply to assume that we all inhabit a single world. For a sceptic about this (such as a devotee of the Sapir-Whorf hypothesis $),{ }^{41}$ nothing I say will have much force. I will also assume the possibility that some of our and their experiences are so different that we cannot talk to each other about them. For a sceptic about all such experiences, however, there will be nothing much here to persuade them

${ }^{41}$ E. Sapir, 'The Status of Linguistics as a Science' (1929), in Sapir, Culture, Language and Personality (ed. D.G. Mandelbaum) (Berkeley: University of California Press, 1958); B.L. Whorf, 'Science and Linguistics' (1940), Technology Review 42: 229-31, 247-8, reprinted in Whorf, Language, Thought and Reality (ed. J.B. Carroll) (Cambridge, MA: MIT Press, 1956). 
WARNING - AUTHOR COPY ONLY. NOT OFFICIAL PUBLICATION. NOT

FOR CITATION. OFFICIAL VERSION IS PUBLISHED IN: The Southern Journal of Philosophy 52 (2014): 206-26

out of their scepticism. It might be objected at this point that I have made

my case easy by shunting aside all the most interesting and pressing

objections! Yet all of these general sceptical worries can be applied, and

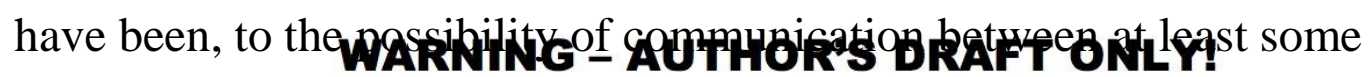

Homo sapiens and others Dewe all inhabit a singlew world?

carve it up in the same way? Are our experiences commensurable? If this SEE ABOVE FOR OFFICIAL PUBLISHED

is what bothers you, then you will see the question of transhumanist

VERSION.

species membership as just more of the same. I am not bothered by any of

this: I take it for granted that all Homo sapiens can in principle

communicate with each other. What I am concerned with is the case of

radically different rational animals. And here is where a more interesting

objection comes into play, namely that whereas communication between

Homo sapiens is possible precisely because of our identical body plan -

the animal part of our natures - this will not be the case with a radically

different rational animal. Moreover, we can ignore sceptical worries

about how our fellow Homo sapiens experience the world since we make

sound inferences to the best explanation of how they function in terms of

how their bodies causally interact with their surroundings.

So consider a mythical rational animal, Glog. He/she - better it -

has three heads full of liquid hydrogen, seventeen sensory organs, and

twelve tentacles of varying lengths placed strategically around a spherical 
WARNING - AUTHOR COPY ONLY. NOT OFFICIAL PUBLICATION. NOT

FOR CITATION. OFFICIAL VERSION IS PUBLISHED IN: The Southern Journal of Philosophy 52 (2014): 206-26

body of thixotropic clay. For nutrition it sucks in helium through a glass

tube, expels xenon as waste, reproduces by shaking itself into liquid pools that reassemble into similar bodies, and gets about by magnetic levitation.

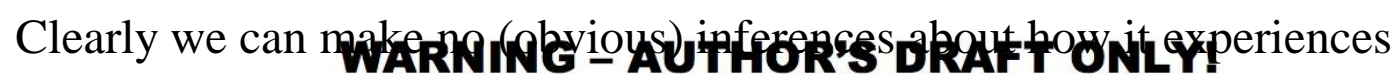
the world from jtscausal interaction with the environment call Glog a human being, but isn't that simply incredible? Not if you SEE ABOVE FOR OFFICIAL PUBLISHED

remember that Glog is rational. Glog will, as I argued, attempt to

\section{VERSION.}

communicate with us Homo sapiens, barring lack of interest or some

other contingent environmental factor. If its alien language is

untranslatable, that will only be for technical reasons, not reasons of principle. We might not be smart enough to decipher what Glog is saying.

We might not have the sensory organs for receiving its mode of communication. A host of reasons such as these might prevent uptake.

But why should they prevent us from counting Glog as one of us? What reason of principle is there for saying that we could never communicate with each other? Suppose we could. Glog speaks via microwave pulses, so we use a microwave pulse detector to pick up the signals. Where we see trees, Glog sees vibrating atoms; so we tool up some appropriate scanning tunnelling microscopy for seeing what Glog sees. If we notice Glog acting as though in distress in a helium-deficient environment such as a chamber filled with xenon, we might think about adding some 
WARNING - AUTHOR COPY ONLY. NOT OFFICIAL PUBLICATION. NOT

FOR CITATION. OFFICIAL VERSION IS PUBLISHED IN: The Southern Journal of Philosophy 52 (2014): 206-26

helium and taking out some xenon. And so on. Presumably Glog will try to thank us! Might it thank us by trying to exterminate us? If you think that a possibility, then you haven't understood what it means to express

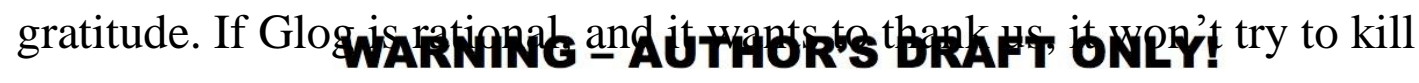
us. If it is rational grateful and evil it might, but that's a different matter.

All of this is fun speculation, the stuff of which careers in science SEE ABOVE FOR OFFICIAL PUBLISHED

fiction are made. The philosophical point is that, being rational, Glog has VERSION.

the characteristics I listed earlier. Glog will have a life plan; it will be able to order priorities and objectives; it will worry and wonder about things, try to solve its deepest problems, consider its mortality, ${ }^{42}$ contemplate the world and its own mind, and when it encounters us Homo sapiens, wonder about just what we are like, having a mirror image of the concerns we have about it. Technical problems aside, once we get some basic communication going, what more is there to add if we are to count Glog as one of us - a human, i.e. a rational animal? The word 'human' is what creates so much of the roadblock to thinking in this way about exotic rational animals. We take it to be a term whose extension is exclusively biologically determined, but where 'biological' has a narrow sense encompassing only genetics, phylogenetics, and the study of

\footnotetext{
${ }^{42}$ I take physical immortality not to be an option if the laws of nature are as we think they are.
} 
WARNING - AUTHOR COPY ONLY. NOT OFFICIAL PUBLICATION. NOT

FOR CITATION. OFFICIAL VERSION IS PUBLISHED IN: The Southern Journal of Philosophy 52 (2014): 206-26

vegetative (and to some extent sensory) function. Here already we go

astray since, being an animal, Glog does have the same vegetative and

sensory functions as us at the appropriate level of generality. ${ }^{43}$ Having

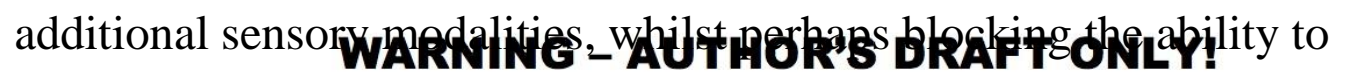

communicate aboutsome aspect of reality doesnot obstruct all

communication; nor does having the same modalities but using them in a SEE ABOVE FOR OFFICIAL PUBLISHED

different way. Glog still picks up particular sensory information,

\section{VERSION.}

processes it, forms concepts and composes them into judgments and

inferences. If there were some other way for a bodily creature to know

about the world, it would be interesting to learn what it was.

We go wrong more significantly in conceiving of biology in an

unduly restrictive way. When biologists, as they usually do in describing

Homo sapiens, refer to the manifestations of rationality, not just

animality, are they doing biology? In the narrow sense, no: they should

stick to genetics and descent. In the broad sense, of course they are: to do

biology in this sense you have to do psychology as well. Indeed, it is the

Aristotelian's lament that psychology, which used to mean 'the science of

life' ( $p s \bar{u} c h e=$ life principle), has, in relatively recent history, become the

\footnotetext{
${ }^{43}$ For a view in agreement with this and with my overall position, though without the detail, see P. Toner, 'Hylemorphic Animalism', Philosophical Studies 155 (2011): 6581, at pp.78-9.
} 
WARNING - AUTHOR COPY ONLY. NOT OFFICIAL PUBLICATION. NOT

FOR CITATION. OFFICIAL VERSION IS PUBLISHED IN: The Southern Journal of Philosophy 52 (2014): 206-26

science of the mind, with biology narrowly conceived being split off into a different discipline - as though you could study rationality without ipso facto studying animality, and vice versa.

To think cWrAktViRe ourselves to think of the term ‘buman' in more broadly biological terms, or else abandon it pro tem and just use the term 'rational animal'. This SEE ABOVE FOR OFFICIAL PUBLISHED

will enable us to put methodological bias to one side and consider simply VERSION.

the metaphysics of the matter. Metaphysically, Glog is one of us in all that counts.

Finally, before putting Glog to rest, we should note the following. There is, of course, a very important sense in which Glog is not one of us, any more than a Great Dane is one of the Chihuahuas. Glog is not a distinct species from us under the genus rational animal. Rather, it is a distinct variety from us under the infima species rational animal. That we and Glog could not interbreed is, as we know, not a defeater for being of the same species even in the narrow biological sense (let alone the broader one): ring species, such as the Ensatina salamander (Ensatina eschscholtzii) in California and the Greenish Warbler (Phylloscopus trochiloides) in the Himalayas both contain extreme varieties that cannot 
WARNING - AUTHOR COPY ONLY. NOT OFFICIAL PUBLICATION. NOT

FOR CITATION. OFFICIAL VERSION IS PUBLISHED IN: The Southern Journal of Philosophy 52 (2014): 206-26

interbreed. $^{44}$ This does not mean that, taxonomically, we should put Glog and Homo sapiens on the same level as, say, Asians and Africans or men and women. Biology, especially botany, has and continues correctly to maintain various and other differences between members of the same species. Speaking fairly loosely, I would put Glog at the level of Homo sapiens as varieties SEE ABOVE FOR OFFICIAL PUBLISHED

or subspecies of rational animal (note: a subspecies is not a species any VERSION.

more than a rubber duck is a duck), male and female as subvarieties of Homo sapiens (if Glog has a gender, do the same), and the different races as different forms of each of the two subvarieties (where 'form' is not used in the overarching Aristotelian sense but in a sense more akin to botany).

\section{Superhumans}

Exotic rational animals of the type exemplified by Glog are decidedly not what transhumanists have in mind when they speak, as they sometimes do, of a new posthuman species. What they are thinking of is an animal that is bigger, better, brainier than us poor Homo sapiens, enhanced by

\footnotetext{
${ }^{44}$ For these examples and more, and a discussion of ring species in general, see M.A. Patten, 'Evolution and Historical Biogeography of a Song Sparrow Ring in Western North America', in P. Pontarotti (ed.) Evolutionary Biology: Concepts, Molecular and Morphological Evolution (Heidelberg: Springer, 2010): ch.20.
} 
WARNING - AUTHOR COPY ONLY. NOT OFFICIAL PUBLICATION. NOT

FOR CITATION. OFFICIAL VERSION IS PUBLISHED IN: The Southern Journal of Philosophy 52 (2014): 206-26

technology. So why bring exotic creatures into the picture? The reason is that if we can make the case for a Glog-like being to be one of us, a human in the metaphysical sense, then we can surely make the case for

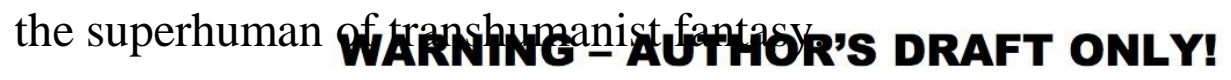
We cannot take the easy yay out by arguing that since what transhumanists have in mind is a superhuman, all they are really speaking SEE ABOVE FOR OFFICIAL PUBLISHED

of is a human being with enhanced powers, and so a fortiori a human VERSION.

being. Nor, contrarily, can we argue that since what they have in mind is something like Superman, they mean a distinct species of human-looking creature, human on the outside but all special powers beyond human ken on the inside. What we have to do is to think about the sort of exotic case I have outlined: if such a creature were indeed one of us, why wouldn't the same apply a fortiori to any creature engineered on this earth according to the laws of nature prevailing here, using pre-existing human material (distasteful though this terminology may be)? Such a being could only be more like Homo sapiens in appearance, structure, and function, than any exotic being we could dream of.

At this point I want to advance an a priori argument, wholly general in nature, that in my view guarantees the falsity of the extreme transhumanist claim that we could engineer a new species. In considering Glog-like cases, I had in mind only the question of horizontal species 
WARNING - AUTHOR COPY ONLY. NOT OFFICIAL PUBLICATION. NOT

FOR CITATION. OFFICIAL VERSION IS PUBLISHED IN: The Southern Journal

of Philosophy 52 (2014): 206-26

difference, by which I mean the question of whether there could be a non-

human rational animal that, although extremely different from us in many ways, was not necessarily more capable than us of doing anything in

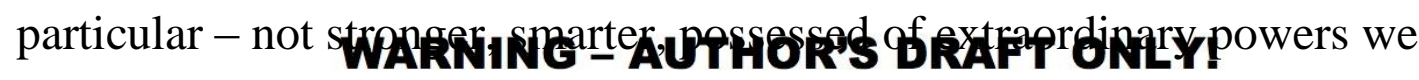
could only wish we had and so on. The transhumanist, by contrast, thinks a new species would be an example of vertical difference - a species SEE ABOVE FOR OFFICIAL PUBLISHED

made distinct precisely by its superhuman powers of cognition, strength,

\section{VERSION.}

speed, agility, extended lifespan, resistance to damage, capacity to heal itself, and the like. Would these sorts of transcendent powers make for a new species?

My answer is the old Aristotelian-Scholastic maxim: plus vel minus non mutat speciem. No difference of degree could ever change the species. Knowing more, living longer, being stronger...none of these could ever turn a human into a non-human, or be that in virtue of which one being was human and another not. All would be rational animals, humans in the true metaphysical sense regardless of how we classified them based on narrow biology alone. Here is the a priori argument in full. A superhuman in the transhumanist sense either has more rationality or more animality. (For example, if it knows more it has more rationality; if it is stronger it has more animality. This is a deliberately forced way of speaking, but I cannot think of a preferable way of making the point.) No 
WARNING - AUTHOR COPY ONLY. NOT OFFICIAL PUBLICATION. NOT

FOR CITATION. OFFICIAL VERSION IS PUBLISHED IN: The Southern Journal of Philosophy 52 (2014): 206-26

difference of degree can make for a difference of species. So the

superhuman would still be of the same species, namely a rational animal.

How, then, could a new but superior non-human species be brought into

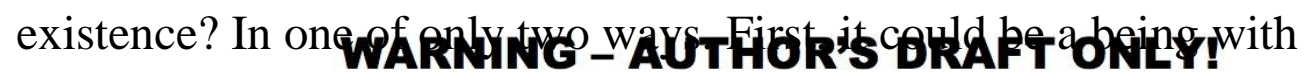
rationality but withoutanimality ${ }^{45}$ It would, in otherwords have to be a

\section{SEE ABOVE FOR OFFICIAL PUBLISHED}

${ }^{45}$ It might be objected that a rational being that lacked animality would not have to be VERSION,

a disembodied mind/spirit. It could be an 'upload', as the transhumanist terminology has it - a person transferred from their original body to an inorganic substrate of silicon and circuitry or whatever materials were necessary for such a process. (For a nice overview, see Bostrom, 'The Transhumanist FAQ', sec. 2.6.) Even by the standards of transhumanist thought experiments, 'uploading' scenarios make enormous presuppositions both about what is physically and/or metaphysically possible and about personal identity. But even if we grant that some futuristic technology could preserve a person's identity via 'uploading', the person would not have turned into a new species of embodied (or at least spatio-temporally located) rational being that was not at the same time an animal. For the person to be remotely capable of functioning, she would need some kind of body to enable her to interact with the world and with other persons. She would need perceptual organs, without which she would not be able to take in the data required for even basic mental operations. If the 'upload' really were a person, she would have to be capable of sensory, affective and volitional behaviour. The sort of body able to make that possible would have to possess the basic features of any animal body, no matter the specific differences from a typical human body made of biological material. I can see 
WARNING - AUTHOR COPY ONLY. NOT OFFICIAL PUBLICATION. NOT

FOR CITATION. OFFICIAL VERSION IS PUBLISHED IN: The Southern Journal of Philosophy 52 (2014): 206-26

disembodied rational creature - a spirit or, as traditional theists hold, an angel. Secondly, it could be something even more extreme - a being without rationality or animality in the senses in which I have

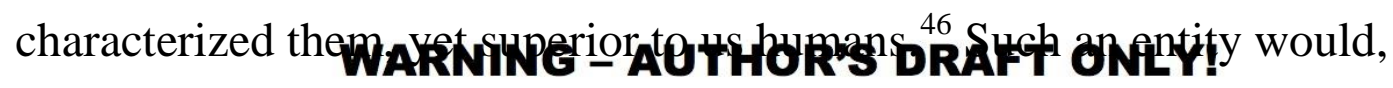
quite simply, be God. God is not an animal in the sense of having a body that carries out the vegetative and sensory functions. Nevertheless, on the SEE ABOVE FOR OFFICIAL PUBLISHED

traditional conception God perceives and acts, and is considered

\section{VERSION.}

(analogically) to be a living being. Nor is God rational in the sense of composing and dividing concepts, making judgments and drawing inferences. Yet in another sense God is supremely rational because He is omniscient. An omniscient being does not need to put two and two together to get four, as it were: there is nothing to be composed or divided, no judgments to be made or inferences drawn, no reasoning to carry out, because an omniscient being already knows all the connections between everything without exception. We can, by analogy, still call this a kind of rationality.

no more reason for denying that such a person were one of us than for denying it of our mythical exotic alien.

${ }^{46}$ It could not have animality without rationality and still be superior, so that option is ruled out. 
WARNING - AUTHOR COPY ONLY. NOT OFFICIAL PUBLICATION. NOT

FOR CITATION. OFFICIAL VERSION IS PUBLISHED IN: The Southern Journal of Philosophy 52 (2014): 206-26

So where does that leave us? The only way a rational animal could become something greater and distinct in species is by losing its animality or its rationality in the way just described. It would have to

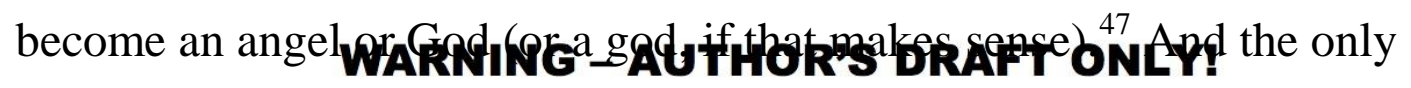
way an entity could exist that was both superior to and distinct from rational animals is by being either an angel or God (or a god). It is SEE ABOVE FOR OFFICIAL PUBLISHED

obvious that no human being can be God (or a god), or of the same VERSION.

species as God (or a god). ${ }^{48}$ But humans would not be of the same species as any angel either since, being disembodied, angels have a wholly different means of cognition: at no level of generality can they be said to

\footnotetext{
${ }^{47}$ On the traditional scholastic view, God is not a member of any species. So I am really speaking of God as a being of a wholly different order to the species rational animal. Angels, on the other hand, are argued by St Thomas Aquinas to be all singleton members of distinct species: see Summa Theologica I, q.50, a.4 on the angels (Eng. trans. by the Fathers of the English Dominican Province, vol. 3, London: Burns Oates and Washbourne, 1922: 13-14); on God as not being a member of a species, see ST I, q.3, a.5 (vol. 1, London: R. and. T. Washbourne, 1911: 37-9). ${ }^{48}$ Not just because God is not a member of any species. Even if He were, he would not be of the same species as human beings.
} 
WARNING - AUTHOR COPY ONLY. NOT OFFICIAL PUBLICATION. NOT

FOR CITATION. OFFICIAL VERSION IS PUBLISHED IN: The Southern Journal of Philosophy 52 (2014): 206-26

know things in the same way that humans know them. ${ }^{49} \mathrm{I}$ can see how, to borrow a phrase from Wyndham Lewis, transhumanists might seek to be the apes of God, but I hope I do not have to argue for the proposition that

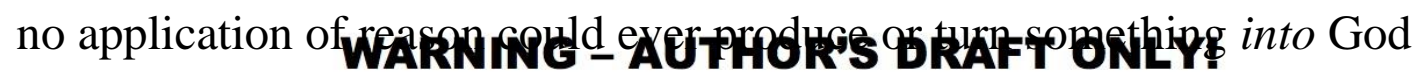
or a spirit.

\section{Conclusion sêEethiglimplíRtiop FICIAL PUBLISHED}

If what I have argued is correct. it is nomore than an exemplification of the thesis that there is and can be nothing in between humans and angels. If there is an ontological hierarchy, as I believe, then from God we descend to spirits and then human beings. There is no space between the rational animals and the disembodied spirits, metaphysically speaking.

Superhumans, therefore, will always be one of us no matter how different they seem. At which many will wonder - who cares? What difference does it make whether we correctly call a posthuman or superhuman a member of our species or a member of a distinct species? One might, in other words, wonder whether the issue is more than a verbal one. Suppose the transhumanist concedes the metaphysical point: a superhuman would not belong to a new species distinct from human

\footnotetext{
${ }^{49}$ Angels are traditionally held to know things by a kind of intellectual apprehension, a direct knowledge unmediated by sensory impulses. For Aquinas on angelic knowledge, see ST I, qq.54-58 (vol. 3: 41-94).
} 
WARNING - AUTHOR COPY ONLY. NOT OFFICIAL PUBLICATION. NOT

FOR CITATION. OFFICIAL VERSION IS PUBLISHED IN: The Southern Journal of Philosophy 52 (2014): 206-26

beings; both it and we would all belong to the rational animal kind.

Nevertheless, the superhuman would be a superior 'variety', so to speak, of rational animal. As the Mastiff is to the Poodle in strength; as the

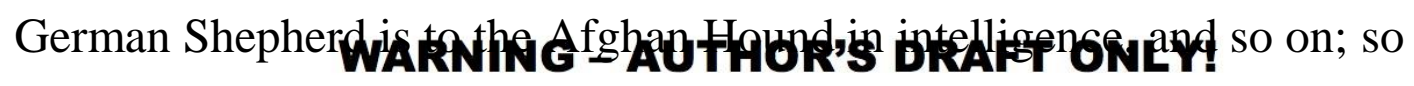
the superhuman would be to the ordinary human multiplied by much

larger factors. The facts that matter - that are of any practical interest SEE ABOVE FOR OFFICIAL PUBLISHED

would be the same, whatever the species allocation.

\section{VERSION.}

I propose, however, at least one rather interesting and surprising ethical implication that does make this more than an abstruse metaphysical question - contra Harris's thought mentioned earlier that species allocation is of no ethical consequence. One of the issues transhumanists worry about is whether a future posthuman class would inevitably dominate and enslave the existing human population. ${ }^{50}$ I tend to side with the more pessimistic view, but what interests me is the nature of any such conflict assuming the correctness of what I have argued. It is an old truth that civil wars are usually nastier, bloodier, and more traumatic than those fought against an outside enemy. If our posthuman class were indeed of a different species - if we did not recognize them as one of us - any purported domination of us by them would parallel the invasion of one nation by another, and our self-defence would be

\footnotetext{
${ }^{50}$ See, for example, Bostrom, 'The Transhumanist FAQ', sec. 3.9.
} 
WARNING - AUTHOR COPY ONLY. NOT OFFICIAL PUBLICATION. NOT

FOR CITATION. OFFICIAL VERSION IS PUBLISHED IN: The Southern Journal of Philosophy 52 (2014): 206-26

something like collective resistance against an external aggressor. Such

wars generate much internal unity and cohesion in the face of the outside threat. Differences are put aside and people rally together to defeat the common foe. WARNING - AUTHOR'S DRAFT ONLY! By contrastocivil wars are messy and shocking affairs in a more unpleasant way. Brother fights brother, neighbours and relatives can find SEE ABOVE FOR OFFICIAL PUBLISHED

themselves in arms against each other, the common land is laid waste and VERSION.

everyone suffers. The scar on the national psyche is long lasting, whoever wins. Now, if the transhuman class really were one of us, any attempt by it to subjugate the 'unenhanced' humans, coupled with our resistance to their threatened domination, would result in a civil war. True, we would have to recognize the transhuman class as one of us, and as I indicated earlier, people have sometimes made mistakes about whether other humans belong to their species. So it is contingent whether a de facto civil war would be seen as such, with all the psychic and emotional consequences. But we should now be thinking not of the far-fetched, Glog-like case, which I used to make a metaphysical point about species membership even at the extreme end (and about likely mutual recognition), but of the far more realistic scenarios transhumanists have in mind. In these, super-engineered 'posthumans' are far more likely to be recognized as beings of our own species - albeit privileged over the 
WARNING - AUTHOR COPY ONLY. NOT OFFICIAL PUBLICATION. NOT

FOR CITATION. OFFICIAL VERSION IS PUBLISHED IN: The Southern Journal of Philosophy 52 (2014): 206-26

rest of us to a prodigious degree. One might dispute my claim that even in the exotic case, sufficient interaction across enough dimensions and for a long enough period of time would likely lead to mutual recognition of

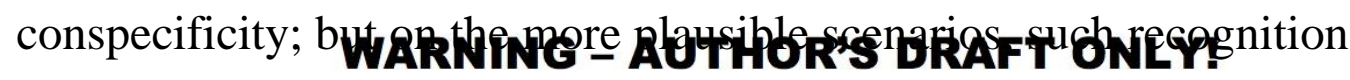
seems all but guaranteed. For CITATION OR CIRCULATION.

Now, whether Homo sapiens or our transhuman brothers emerged SEE ABOVE FOR OFFICIAL PUBLISHED

victorious in the war of domination, some humans would have to crush

\section{VERSION.}

members of their own species; this must have a traumatic psychological effect of a different order from that involved in subjugating a distinct species. (If a lion could speak, the first thing he would express is his shock at our callously easy exploitation of his kind.) Were the transhumans to triumph, the result would not be analogous to the temporary occupation of a foreign land. Rather, it would be the permanent occupation of one's own land by one's own kind - a conspecific boot on the human face forever. Even absent outright conflict, resentment at extreme inequality, leading to a virtually permanent state of unrest, would be guaranteed - just as, again by imperfect analogy, people are naturally far more agitated about there being obscenely and disproportionately rich people in their own country than they are about those in some other land. Unable to transcend our own species, then, pessimistic transhumanism requires the human race to 
WARNING - AUTHOR COPY ONLY. NOT OFFICIAL PUBLICATION. NOT

FOR CITATION. OFFICIAL VERSION IS PUBLISHED IN: The Southern Journal of Philosophy 52 (2014): 206-26

turn on itself. I for one hope that the limits of 'applied reason' will keep

such an awful spectacle forever at possible world's length. ${ }^{51}$

\author{
WARNING - AUTHOR'S DRAFT ONLY! \\ NOT FOR CITATION OR CIRCULATION. \\ SEE ABOVE FOR OFFICIAL PUBLISHED
}

VERSION.

\footnotetext{
${ }^{51}$ An earlier version of this paper was delivered in 2012 at the Wake Forest University conference on Engineering Human Nature and the Future of Human Values. I am grateful to Kevin Jung, organizer of the conference, for the invitation, and to the audience for their comments. I would also like to thank two anonymous referees for a number of suggestions that have further improved the paper.
} 